\title{
Application of sorption tests to estimate selected properties of alluvial soils in Żuławy Elbląskie
}

Andrzej OLCHAWA ${ }^{1)}$, Jerzy TERLIKOWSKI ${ }^{2)}$

1) University for Technology and Life Sciences, Department of Geotechnics, ul. S. Kaliskiego 7, 85-796 Bydgoszcz, Poland; e-mail: andyolchawa@wp.pl

${ }^{2)}$ Institute for Technology and Life Sciences, Żuławski Research Centre in Elblag, ul. Giermków 6, 82-300 Bydgoszcz, Poland; e-mail: itepelb@itep.edu.pl

\begin{abstract}
The specific surface area and hence the sorption or desorption moisture at constant water vapour pressure will increase with increasing content of humus and clay fraction in soils. Adopting such an assumption, preliminary experimental studies were performed to assess the possibility of using sorption/desorption tests to determine some features of alluvial soils from Żuławy such as cation exchange capacity $C E C$ and the specific external surface area $S_{e}$. Results of the sorption tests were compared with the analyses of the same soil properties determined with standard methods to evaluate the usefulness of the former. Preliminary studies showed a high similarity in the determination of $C E C$ and $S_{e}$ with both methods. Confirmed usefulness of sorption/desorption methods for determination of the specific surface area of mineral soil particles and particularly for analyses of cation exchange capacity would bring a significant simplification of studies and a possibility of their dissemination due to the ease of such analyses. Determination of the specific surface area with the sorption and desorption method does not require sophisticated equipment and laborious and costly preliminary procedures. Dissemination of this method and recognition it as a reference one would, however, need further studies on various soil types.
\end{abstract}

Key words: alluvial soils, cation exchange capacity, external surface area of mineral phase of soils, statistical analysis, water desorption moisture, water sorption test

\section{INTRODUCTION}

The specific surface area of soils, and particularly its external surface, is, among others, a parameter determining retention properties and cation exchange capacity.

The specific surface area of soils is the area per unit mass and its value increases with the content of mineral (clay) and organic (humus) colloids (WALCZAK, 1984). Clay fraction is built mainly of clay minerals such as kaolinite, illite and montmorillonite. Kaolinites and illites belong to the so-called non- 
swelling minerals which means that all surface phenomena take place exclusively on the external surface. Montmorillonite is a swelling mineral and, apart from the external surface, has a between-package internal surface which is available to water molecules and exchangeable ions (adsorbate particles).

In mineral soils i.e. in such having less than $2 \%$ of organic matter $(\mathrm{PN}-86 / \mathrm{B}-$ 02480), cation exchange capacity $C E C$ is proportional to the external specific surface area $S_{e}$ and may be calculated from statistically significant correlations $C E C=$ $C E C\left(S_{e}\right)$ (GORĄCZKO, 2007; PIASKOWSKI, 1984; STĘPKOWSKA, 1977; SRIDHARAN et al., 1988;). The specific external surface area of mineral grounds and soils may be determined based on the results of sorption or desorption tests at a relative water vapour pressure $p: p_{\mathrm{o}}=0.5$ adopting assumptions on the properties of water adsorbed on or desorbed from surfaces of clay mineral particles (STĘPKOWSKA, 1977; OLCHAWA, 1994). Humus is, in some aspects, similar to clay minerals (UGGLA, 1983) but the determination of specific surface area of soils with the sorption test is not possible due to a lack of information on the properties of water adsorbed or desorbed from humic particles.

The specific surface area and thus the sorption moisture at a constant water vapour pressure will increase with the increased content of humus and clay minerals in soils. Having adopted such assumptions, preliminary experimental studies were undertaken to assess a possibility of using sorption/desorption tests to estimate cation exchange capacity and the external specific surface area $S_{e}$ of the mineral solid fraction of alluvial soils from Żuławy. The usefulness of sorption tests was evaluated by comparing the results with those obtained with standard, reference methods.

\section{MATERIAL AND METHODS}

Alluvial soils from Helenowo, Kazimierzowo and Józefowo situated in the depression of Żuławy Elblaskie were taken for this study. The villages are located several kilometres west of Elblag. Soil samples were collected in July 2009 from four places. Alluvial humic soils formed under the effect of three simultaneous processes: alluvial, sward forming and bogging and dominating in this region were selected for the study. Soil habitats were classified as cereal-fodder strong complex (TERLIKOWSKI, 2008). Soil profile structure, humus content and the past and present soil utilization are given in Table 1.

Organic matter content was calculated as a loss on ignition at a temperature of 378-713 K (BS-1377, 1990).

Collected soil samples were carefully mixed and placed in tightly closed foil bags for 4 weeks to equilibrate moisture. Then, 15 soil samples from each sampling site of a mass of c. 7-10 g were prepared. Desorption test started with placing so prepared soil samples in a desiccator above the saturated solution of magnesium 
Table 1. Characteristics of soil habitats

\begin{tabular}{|c|c|c|c|}
\hline Village & $\begin{array}{l}\text { Description of soil } \\
\text { profile }^{1)}\end{array}$ & $\% \mathrm{SOM}^{2)}$ & Notes \\
\hline Helenowo & $8 \mathrm{~F} \mathrm{bc} \cdot \mathrm{pl}$ & 6.90 & $\begin{array}{l}\text { arable land for } 15 \text { years, permanent meadow } \\
\text { before, now - winter wheat }\end{array}$ \\
\hline Helenowo & $8 \mathrm{~F} \mathrm{bc} \cdot \mathrm{pl}$ & 9.95 & intensively managed permanent meadow \\
\hline Józefowo & $8 \mathrm{~F} \mathrm{~s} \cdot \mathrm{bl}$ & 14.51 & $\begin{array}{l}\text { arable land for } 8 \text { years, permanent meadow be- } \\
\text { fore, now maize for ensilage }\end{array}$ \\
\hline Kazimierzowo & $8 \mathrm{~F} \mathrm{~s}$ & 8.24 & extensive permanent meadow \\
\hline
\end{tabular}

1) Acc. to PTG 1989. ${ }^{2)}$ Soil organic matter.

Explanations: 8 - strong cereal-fodder complex, F bc·pl - very heavy alluvial soil, shallow, underlined with loose sand, F s.bl - medium alluvial soil, shallow, underlined with very light alluvial soil, F s - medium alluvial soil.

nitrate $\left(\mathrm{Mg}\left(\mathrm{NO}_{3}\right)_{2}\right)$. Under such conditions the relative water vapour pressure was $p / p_{0}=0.5$ at a temperature of $293 \mathrm{~K}$ (OLCHAWA, 1994).

Samples stayed in the desiccator until the thermodynamic equilibrium was achieved between water vapour above the solution and water in the soil. The equilibrium was assumed to be achieved when the mass of soil samples remained constant (DUDKIEWICZ, 1998).

After the end of desorption process, soil samples were dried for $24 \mathrm{~h}$ at $378 \mathrm{~K}$ $\left(105^{\circ} \mathrm{C}\right)$ and their desorption moisture $\mathrm{WD}(0.5)$ was calculated. The same soil samples were then combusted for $2 \mathrm{~h}$ at $723 \mathrm{~K}\left(450^{\circ} \mathrm{C}\right)$ and subsequently at $873 \mathrm{~K}$ $\left(600^{\circ} \mathrm{C}\right)$. Organic matter content was determined based on relative mass losses after combustion in the range of 378-723 K (acc. to BS-1377) and in the range of 378$873 \mathrm{~K}$ (acc. to PN-88/B-04481)

For the sake of further analyses it was assumed, that combustion of soil samples at $873 \mathrm{~K}\left(600^{\circ}\right)$ had removed organic matter but also caused irreversible collapse of the unit layers of montmorillonite present in the ground (OLCHAWA, 1994). It meant that surface phenomena in so modified soil would take place exclusively on the external surface of mineral soil particles.

Combusted samples were placed in a desiccator above the saturated solution of magnesium nitrate. The specific external surface area of mineral soil particles $S_{e}$ was calculated from the sorption moisture $W S(0.5)$ acc. to the formula (STĘPKOWSKA, 1977):

$$
S_{e}=\frac{W S(0.5)}{n \phi \rho} k
$$

where:

$N$ - the number of water molecule layers on the external surface of soil particles; $n=1.9$;

$\phi-$ diameter of water molecule; $\phi=27,6 \mathrm{~nm}$; 
$\rho$ - density of water adsorbed from gaseous phase on the particle surface; $\rho=$ $1,27 \mathrm{Mg} \cdot \mathrm{m}^{-3}$

$K$ - correction coefficient considering the decreased specific surface area after combustion of clay minerals (PIASKOWSKI, 1984); $k=1.07$

After substitution of these values, equation (1) assumes a form:

$$
S_{e}=15.37 m^{2} \cdot g^{-1} W S(0.5)
$$

where:

$W S(0.5)$ - the gravimetric sorption moisture of the soil expressed in percent at a relative vapour pressure of $p / p_{0}=0.5$ and a temperature of $293 \mathrm{~K}$.

For comparative purposes, the external surface area of mineral soil particles was determined from the sorption capacity of methylene blue (MBC). The determination was made according to p.4.3 PN-88/B-0448. The external surface area of mineral particles $S_{e}$ was calculated from the equation:

$$
S_{e}=n N s_{d}
$$

where:

$n$ - the number of moles of methylene blue adsorbed on $1 \mathrm{~g}$ of soil mass;

$N$ - Avogadro's number $=6.023 \cdot 10^{23}$;

$s_{d}$ - the surface area of a single molecule of methylene blue $=1.02 \cdot 10^{-18} \mathrm{~m}^{2}$.

Mole of methylene blue was $320 \mathrm{~g}$.

Cation exchange capacity was determined acc. to PN-ISO 13536/2002. This international standard is applicable to all air dry soil samples. The method consisted in saturating the soil sample with barium through triple extraction with buffered (by tris-ethylenediamine) solution of barium chloride. Then, a known excessive amount of magnesium sulphate of a concentration of $0.02 \mathrm{M}$ was added. The whole amount of barium present in solution and adsorbed precipitated in a form of hardly soluble barium sulphate and ion exchanging centres were occupied by magnesium. The excess of magnesium was determined with the flameless atomic absorption spectrophotometry using PU-9100X, Philips spectrophotometer.

From each sampling point (Tab. 1) two soil samples were taken for analyses (8 samples in total).

\section{RESULTS}

Checking a possibility of using sorption/desorption tests to estimate the specific external surface area of mineral soil particles $S_{e}$ and cation exchange capacity 
$C E C$ consisted in finding the correlations between the specific surface area calculated acc. to PN-88/BB-04481 (methylene blue method) and sorption moisture $W S(0.5)$ and between $C E C$ (based on PN ISO 1353/2002) and desorption moisture $W D(0.5)$. Formal description of these relationships is given by equations: $S_{e[M B C]}=S_{e[M B C]}\left(S_{e[W S(0.5)]}\right)$ and $C E C=C E C[W D(0.5)]$.

Estimators of these equations were found with the least square procedure.

The assumptions for estimation procedure in basic model given in a form:

$$
Y_{i}=\beta_{0}+\beta_{1} X+\varepsilon_{i}
$$

where

$$
I=1,2 \ldots, n
$$

are as follows (NOWAK, 2002):

$\varepsilon_{i} \quad$ - residual variable is a random variable of expected value equal 0 and (unknown) variance $\sigma^{2}$,

$\varepsilon_{i}$ and $\varepsilon_{j}$ are not correlated for $i \neq j$. Moreover, it is postulated that $\varepsilon_{i}$ is a random variable of normal distribution, expected value equals 0 and variance, as in the assumption, $\sigma^{2}=1$ i.e.

$$
\varepsilon_{i} \approx N\left(0 ; \sigma^{2}\right)
$$

If the selected mathematical model is correct, than residual variables should present a tendency of confirming these assumptions. After analysing the residual variables one is able to conclude that the assumptions appear to be not fulfilled or that the assumptions do not appear to be not fulfilled. One of the methods of analysing residual variables is a graph of $\varepsilon_{i}$ regressed on predicted $\hat{Y}_{i}$ values. The accuracy of the regression is assessed by the determination coefficient $R^{2}$, which is a measure of part of variability explained by the regression in the total variability around the mean $\bar{Y}$. $R^{2}$ may be expressed in percent. For example, $R^{2}=85 \%$ means that the regression equation explains $85 \%$ of the total variability.

First degree regression models were used for analyses. Adopted response functions had a form:

$$
\begin{gathered}
S_{e[M B C]}=A S_{e[W S(0.5)]}+B \\
C E C=A W D(0.5)+B
\end{gathered}
$$

Based on 41 sets of paired results $\left(S_{e(M B C)} ; S_{e(W D(0.5))}\right)$ and 8 sets of paired results $(C E C ; W D(0.5))$ the estimators of equations $(6)$ and $(7)$ were calculated and presented in Table 2. 
Table 2. Estimators of equations and statistics

\begin{tabular}{l|c|c|c|c|c}
\hline \multicolumn{1}{c|}{ General form of a function } & $A$ & $B$ & $R^{2}, \%$ & $F$ & $F_{(1 ; n-2 ; 0.95)}$ \\
\hline 1. $S_{e[M B C]}=A \cdot S_{e[W S(0.5)]}+B$ & 0.987 & -0.12 & 92.06 & 1659 & 4.08 \\
2. $C E C=A \cdot W D(0.5)+B$ & 0.0061 & -0.0248 & 90.8 & 59.3 & 5.99 \\
\hline
\end{tabular}

Figure 1 presents the relationship between the specific external surface area of mineral soil particles calculated from the sorption of methylene blue (MBS) and the sorption of water vapour $W S(0.5)$.

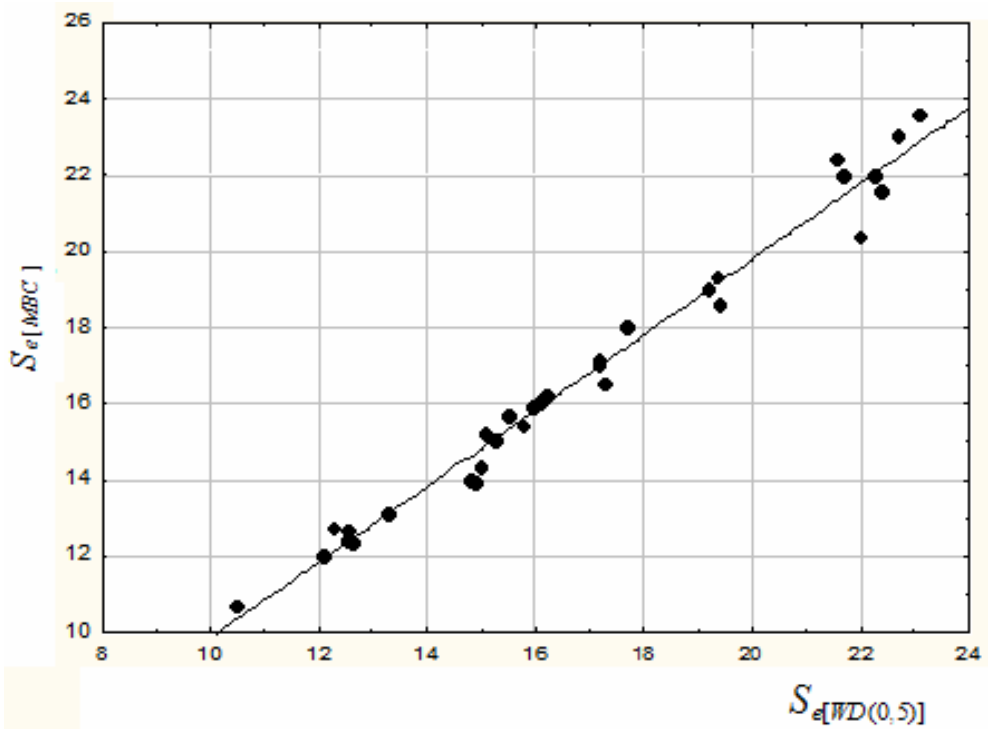

Fig. 1. The relationship between the specific external surface area calculated from the sorption of methylene blue $S_{e(M B C)}$ and the sorption of water vapour $S_{e(W D(0.5))}$

Figure 2.presents the relationship between cation exchange capacity expressed in meq. $\mathrm{g}^{-1}$ and desorption moisture of soils at the relative water vapour pressure $p_{0}: p=0.5$.

Figures $3 \mathrm{a}$ and $\mathrm{b}$ present residuals $Y_{i}-\hat{Y}_{i}$ versus predicted values predicted by the model $\hat{Y}_{i}$. The graphs do not show any oddness which means that the assumptions adopted in the least square procedure did not appear to be not fulfilled.

Coefficients of determination $R^{2}$ for relationships between the same soil properties $\left(S_{e}\right.$ and $\left.C E C\right)$ determined with standard methods and calculated from sorption and desorption of water vapour, respectively, were higher than $90 \%$. It means that the values of the specific surface area and cation exchange capacity calculated from sorption/desorption tests were comparable with those determined with standard methods. 


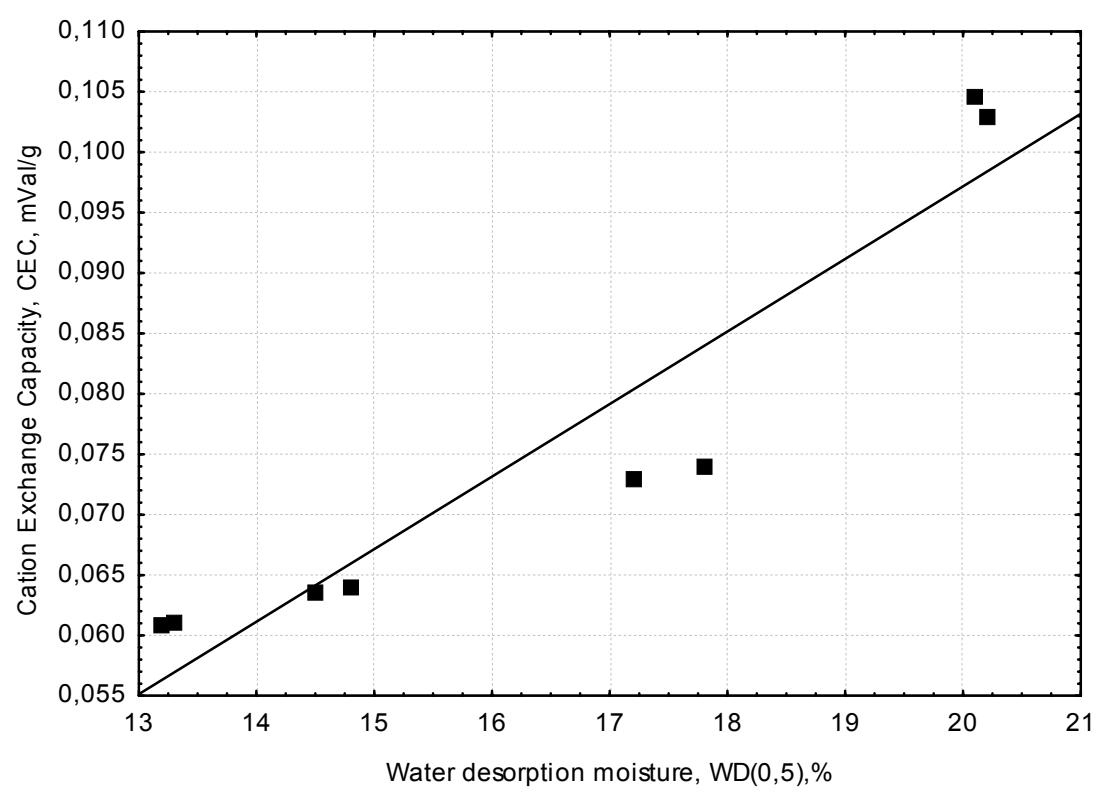

Fig. 2. The relationship between cation exchange capacity and desorption moisture of soils

The external specific surface areas of mineral soil particles calculated from the sorption of methylene blue $S_{e(M B C)}$ were smaller than the values calculated from sorption moisture $S_{e(W D(0.5)) \text {. The differences may result from deviations from }}$ adopted assumptions on orientation or on monomolecular layer of methylene blue covering particle surfaces. Another problem may be in the sorption of methylene blue on edges of clay minerals where surface electrostatic charge is positive.

Functional relationship between cation exchange capacity and desorption moisture was found based on 8 pairs of $C E C-W D(0.5)$ values which did not allow for generalizing it over other types of soils. As assumed, it was a preliminary assessment of a possible application of desorption test to estimate the cation exchange capacity. Confirming such relationships in studies on other alluvial soils in the Vistula River delta would form a basis for simple and cheap method of determining cation exchange capacity in soils from Żuławy.

The method of desorption test may be performed in any soil lab and analysed samples do not pass initial thermal "processing" as it is the case in chemical analyses made with standard methods.

Repeatability of $C E C$ measurements based on desorption moisture may additionally be confirmed by mineralogical composition of soils from Żuławy. Diffraction analyses revealed the presence of illite and kaolinite there; montmorillonite was much less frequent (OLCHAWA, 2003). It means that in most cases, desorption moisture will be a sum of two components: water associated with organic matter and that associated with the external surfaces of clay minerals. 

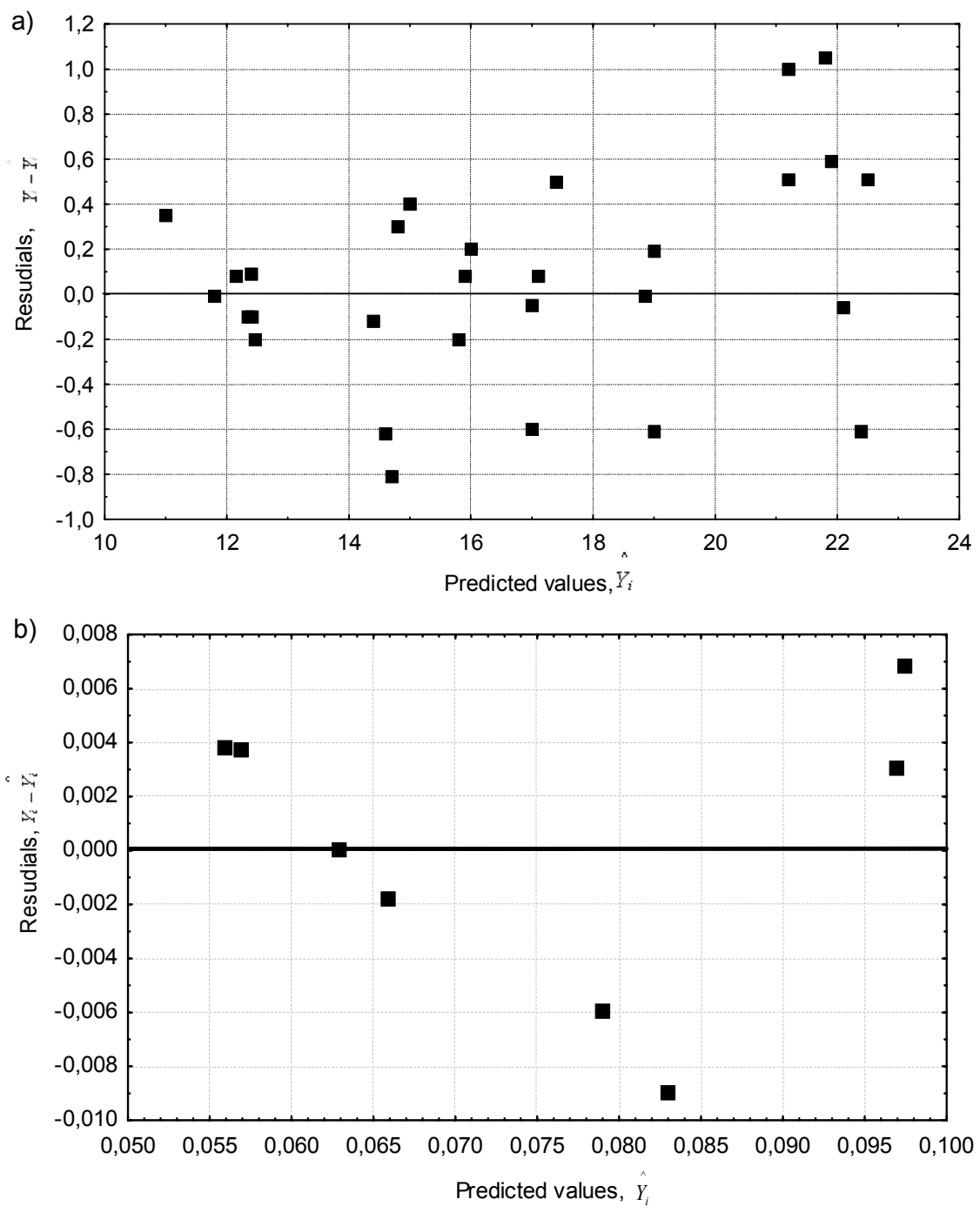

Fig. 3. Residuals versus predicted values for approximated function a) $S_{e(M B C)}=A \cdot S_{e(W S(0.5))}+B$, b) $C E C=A \cdot W D(0.5)+B$

\section{SUMMARY}

The specific surface area and hence the sorption or desorption moisture at a constant water vapour pressure will increase with increasing content of humus and clay fraction in soils. Adopting such an assumption, preliminary experimental studies were performed to assess the possibility of using sorption/desorption tests to determine some features of alluvial soils from Żuławy such as cation exchange 
capacity $C E C$ and the specific external surface area $S_{e}$. Results of the sorption tests were compared with the analyses of the same soil properties determined with standard methods to evaluate the usefulness of the former.

Preliminary studies showed a high similarity in the determination of $C E C$ and $S_{e}$ with both methods. Confirmed usefulness of sorption/desorption methods for determination of the specific surface area of mineral soil particles and particularly for analyses of cation exchange capacity would bring a significant simplification of studies and a possibility of their dissemination due to the ease of such analyses. Determination of the specific surface area with the sorption and desorption method does not require sophisticated equipment and laborious and costly preliminary procedures. Dissemination of this method and recognition it as a reference one would, however, need further studies on various soil types.

\section{CONCLUSIONS}

Performed studies allow for formulating the following conclusions:

1. A highly significant correlation was found between results obtained with standard methods and those obtained from sorption and desorption tests.

2. Coefficient of determination $\left(\mathrm{R}^{2}\right)$ for functional relationships calculated with the least square method was higher than $90 \%$ which proved the usefulness of predictions for the determination of cation exchange capacity and external specific surface area of mineral particles in alluvial soils.

3. Dissemination of sorption and desorption tests will be possible after further detailed studies of a large number of samples taken from various soil types.

\section{REFERENCES}

1. BS - 1377, 1990. Method of test for soils for civil engineering. Part 3. Chemical and electro-chemical tests. London: $1-51$

2. DudKIEWICZ E.T., 1998. Fizykochemia powierzchni. Physical chemistry of surfaces. Warszawa, WNT: $1-242$.

3. GORĄCZKO A., 2007. Badanie przemieszczeń pionowych ekspansywnego podłoża w Bydgoszczy na przykładzie wybranych obiektów. (Analysis of vertical deformation of expansive soil of Bydgoszcz region on the example of some building damage). Doctoral thesis. Bydgoszcz, UTP: 1-139.

4. NowaK R., 2002. Statystyka dla fizyków. (Statistics for physicist). Warszawa. Wydaw. Szkol. PWN: $1-664$.

5. OlchawA A., 1994. Określanie powierzchni właściwej gruntów iłowych na podstawie wilgotności desorpcyjnej. (Determination of surface area of clays from description water content). Wiadomości IMUZ, XVIII, 1: 107-118.

6. OlchawA A., 2003. Właściwości gruntowych kompozytów jako materiału do budowy obwałowań przeciwpowodziowych. (The properties of soil composites as a material for constructing flood embankments). Woda Środowisko Obszary Wiejskie. Rozprawy naukowe i monografie, 8: 1-110. 
7. PIASKOWSKI A. 1984. Właściwości sorpcyjne i powierzchnia właściwa polskich gruntów. Badania nad sorpcją błękitu metylenowego. (Sorption properties and surface area of Polish soils. Investigation on metyleblue adsorption). Archiwum Hydrotechniki, XXXI, 3: 297-314.

8. PN-88/BB-04481. Grunty budowlane. Badania próbek gruntu. (Building soils. Laboratory tests.)

9. PN-ISO 13536, 2002. Jakość gleby. Oznaczanie potencjalnej pojemności wymiennej kationowej i kationów wymiennych z zastosowaniem zbuforowanego roztworu chlorku baru o $\mathrm{pH}=8,1$. (Soil quality. Determination of the potential cation exchange capacity and exchangeable cations using barium chloride solution buffered at $\mathrm{pH}=8.1$ ).

10. SRIDHARAn A., RaO S.M., Murthy N.S., 1988. Liquid limit of kaolinitcs soils. Geotechnique, 38, 2: 191-198.

11. STĘPKOWSKA E., WALA D., 1977. Zastosowanie testu sorpcyjnego do oznaczania powierzchni właściwej i innych cech kaolinów. (Kaolin specific surface and other property determination by water sorption test). Archiwum Hydrotechniki, XXIV, 1: 65-80.

12. TERLIKOWSKI J., 2009. Gospodarka azotem na łące trwałej w warunkach mad próchnicznych na Żuławach Wiślanych. (Nitrogen management on permanent meadow in humus alluvial soils in the Żuławy region.) Zeszyty Problemowe Postępów Nauk Rolniczych, 538: 299-306.

13. WALCZAK R., 1984. Modelowanie badania zależności retencji wodnej od parametrów fazy stałej gleby. (Modeling stadies based on the parameters of the retention of solid phase of soils). Problemy Agrofizyki, 41: 1- 72.

14. UgGLA H., 1983. Gleboznawstwo rolnicze. (Soil Science). Wyd. IV. Warszawa, PWN: 1-557.

\section{STRESZCZENIE}

\section{Zastosowanie testów sorpcyjnych do oznaczenia wybranych cech gleb aluwiach z obszaru Żuław Elbląskich}

Słowa kluczowe: analiza statystyczna, gleby aluwialne, pojemność wymienna kationów, test sorpcji wodnej, wilgotność desorpcyjna, zewnętrzna powierzchnia wtaściwa mineralnej fazy gleby

Celem podjętych badań była próba określenia związków korelacyjnych pomiędzy pojemnością wymiany kationowej (CEC) a wilgotnością desorpcyjną $W D(0,5)$ wybranych gleb na obszarze Żuław Elbląskich. Badania przeprowadzono na madach: bardzo ciężkiej i średniej o zawartości od 6,9 do 14,5\% materii organicznej. Badane gleby były położone na kompleksie zbożowo-pastewnym mocnym. Ponadto $\mathrm{w}$ pracy przedstawiono wyniki badań pomiaru zewnętrznej powierzchni właściwej mineralnej części fazy stałej gleby na podstawie wilgotności sorpcyjnej WS $(0,5)$ i pojemności sorpcyjnej błękitu metylenowego - MBC.

Pojemność wymiany kationowej oznaczono metodą standardową zgodnie z metodyką opisaną szczegółowo w PN-ISO 13536/2002. Wilgotność desorpcyjną gleb oznaczono po zakończeniu procesu ich desorpcji w warunkach względnej prężności pary wodnej $p: p_{o}=0,5 \mathrm{w}$ temperaturze $283 \mathrm{~K}$.

Analiza statystyczna wartości pojemności wymiany kationowej i gleb oraz ich wilgotności desorpcyjnych wykazała istnienie funkcyjnej zależności: CEC = $0,0061 W D(0,5)-0,0248$. Wartość współczynnika determinacji funkcji $R^{2}=90,8 \%$. 
Oznacza to, że wilgotność sorpcyjna może być parametrem do oszacowania wartości pojemności wymiany kationowej. Do uogólnienia i aplikacji tej zależności wymagana jest większa liczba oznaczeń.

Zewnętrzną powierzchnię właściwą mineralnej części fazy stałej gleb wykonano na materiale uprzednio prażonym $\mathrm{w}$ temperaturze $873 \mathrm{~K}$. Zabieg taki zapewnia utlenienie materii organicznej oraz nieodwracalną kontrakcję sieci krystalicznej co oznacza, że wszelkie zjawiska powierzchniowe mogą zachodzić jedynie na powierzchni zewnętrznej. Zewnętrzną powierzchnię właściwą oznaczono na podstawie pojemności sorpcyjnej błękitu metylenowego wg PN-88/BB-04481 i porównano ją $\mathrm{z}$ wartościami obliczonymi na podstawie wilgotności sorpcyjnej $\mathrm{w}$ warunkach względnej prężności pary $p: p_{o}=0,5$. Na podstawie analizy statystycznej wartości zewnętrznych powierzchni właściwych obliczonych na podstawie wilgotności sorpcyjnej - $W D(0,5)$ i pojemności sorpcyjnej błękitu metylenowego - MBC stwierdzono, że istnieje zależność funkcyjna: $S e_{(\mathrm{MBC})}=0,987 S_{e(\mathrm{WS}(0,95))}-0,12$. Wartość współczynnika determinacji funkcji $R^{2}=92,6 \%$. Zależność funkcyjna wskazuje, że wartości powierzchni właściwych, oznaczone obydwiema metodami, są porównywalne.

Wykorzystane w pracach eksperymentalnych właściwości sorpcyjne i desorpcyjne gleb są łatwe do oznaczanie w każdym gleboznawczym lub gruntoznawczym laboratorium. Uzyskane wyniki umożliwiają oszacowanie pojemności wymiany kationowej oraz obliczenie zewnętrznej powierzchni właściwej. Zasadniczą zaletą jest łatwość wykonania oznaczenia i brak konieczności stosowania specjalistycznej aparatury, a wadą - czasochłonność, bowiem czas desorpcji/sorpcji może trwać do 2 tygodni. 